\title{
Implementation of Location Base Service on Tourism Places in West Nusa Tenggara by using Smartphone
}

\author{
Karya Gunawan \\ Academy of Information Management and Computer \\ AMIKOM Mataram \\ Mataram, Indonesia
}

\author{
Bambang Eka Purnama \\ School of Information Management and Computer \\ "Nusa Mandiri”, STMIK Nusa Mandiri \\ Jakarta, Indonesia
}

\begin{abstract}
The study is aimed to create an application that can assist users in finding information about tourism places in West Nusa Tenggara, Indonesia. West Nusa Tenggara is one of the provinces in Indonesia and one of the second tourists' destinations after Bali. It is a small Sunda Island which consists of two large islands located in the west of Lombok and Sumbawa that located in the east to the capital of Mataram on the island of Lombok. The area of West Nusa Tenggara province is 19,708.79 $\mathbf{k m}^{2}$. The application provides information such as descriptions of sights, tourism spot address, photo galleries, and the available facilities and the closest track to where the tourism spot is by using Google maps. Google maps can display map locations and closest routes from the user's position to the tourism place. Determination of the position of the user and position of Tourism sites using GPS (Global Positioning System). This application is made by using the Java programming language for Android with Eclipse 4.2.1 IDE that can be used on the Smartphone device based on Android. The result of the research is the creation of location-based services applications to search a place of Tourism in West Nusa Tenggara province so as to help tourists visiting the West Nusa Tenggara. The benefit of this application is that to determine the path in finding the tourism places.
\end{abstract}

Keywords-location base service; GPS; Smartphone; tourism information

\section{INTRODUCTION}

West Nusa Tenggara Province is one of the provinces in Indonesia. It comprises the western portion of the Lesser Sunda Islands. West Nusa Tenggara Province consists of two large islands situated in the west of Lombok and Sumbawa are located in the east. Mataram city on the island of Lombok is the provincial capital and largest city in the province. The area of West Nusa Tenggara province is 19,708.79 $\mathrm{km} 2$ [1]. West Nusa Tenggara has a Strategic Area Regional Tourism (Indonesian: KSPD) both located on the island of Lombok and Sumbawa islands. KSPD is the area that has the primary function of tourism or have the potential for the development of national tourism that have significant influence in one or more aspects, such as economic growth, social and cultural rights, the empowerment of natural resources, environmental support, as well as defense and security[2]. Lombok as the second tourist destination after Bali has many uniqueness, especially in tourism. In an effort to increase local tourism, the government of West Nusa Tenggara through the Department of Tourism to develop two programs: Visit Lombok-Sumbawa 2015 and Tambora Greet the World. Both of these programs are used as tourist information media of West Nusa Tenggara.
Information is a major requirement for most people. By using mobile devices, information can be obtained wherever the location is within a short time. Mobile devices are the most widely used today is the Smartphone with Android operating system. Besides, it is used to search for information, a Smartphone device can also be used to display the map as well as navigation[3].

The tourists who visit West Nusa Tenggara used Smartphone to search for information of tourist sites. They also used GPS (Global Positioning System) that exist in Smartphone to find the track to the tourist sites[4]. The information of tourism site has not been listed on Google Maps. It caused the difficulty in obtaining information and the correct location. This resulted in the lack of interest of tourists to visit tourist sites in Lombok and Sumbawa. To facilitate the tourists to get valid information about West Nusa Tenggara tourism with a closest track to the tourist sites, it is necessary to have a searching application and the location track of the tourist spots.

The application of tourist spot provides information such as descriptions of sights, address tourist attractions, photo gallery and the facilities available and the closest track to where Google Maps in the form of tourism[5]. Google Maps can display map locations and routes closest to the user's position sought after tourist sites. Determination of the position of the user and position of Tourism sites using GPS (Global Positioning System)[6]. The result of the study is the creation of location-based services applications to search a place of tourism in West Nusa Tenggara province so as to help tourists visiting the West Nusa Tenggara. Benefit from the application of this Smartphone is the closest in terms of determining the path articulated in this study. Not only that, this application can also display a map that can assist travelers in finding the shortest route to the location that will be addressed through the Google Maps APIs.

\section{REVIEW OF RELATED LITERATURE}

\section{A. Android}

Android is a mobile operating system that grew in the middle of other operating systems are evolving today. Other operating systems such as Windows Mobile, i-Phone OS, and Symbian also offer a wealth of content and an optimal to walk on Smartphone devices[7]. However, the existing operating system is running with core apps built prioritize their own 
without seeing the great potential of third-party applications[5].

Android is a new generation mobile platform, the platform provides an opportunity for developers to develop applications according hoped. Android was developed by Google along with the Open handset Alliance (OHA)[8], which is an alliance of mobile device that consists of 34 companies hardware, software and telecommunications to support the development of open source on mobile devices[9].

Some of the main features of Android, among others WiFi hotspots, Multi-touch, multitasking, GPS, support java, supporting multiple networks (GSM / EDGE, IDEN, CDMA, EV-DO, UMTS, Bluetooth, Wi-Fi, LTE, and WiMAX) and also the basic capabilities of mobile phones in general[10].

\section{B. Location Base Service}

Location Based Service is the information service that can be accessed by mobile devices through the network and can display the geographical position where the mobile device [11]. Location Based Service technology works on the lines of Geographic Information System (GIS) and takes aid of Global Position System (GPS) to derive the position of receiver[12]. This technology consists of a device that collect, store, analyze, and distribute data based on the user requirements to the earth coordinate system.

Location based services are divided into two main elements [6]:

\section{1) Location Manager (API Maps)}

Application Programming Interface (API) Maps provide facilities to display, manipulate the map and other features.

\section{2) Location Providers (API Location)}

Location providers provide location search technology used by the device. API location associated with GPS data and location data in real time. By Location providers we can determine the user's location at this time, displacement and proximity to certain locations[13].

\section{Google Maps}

Google Maps is a free online map service provided by Google. In addition to providing free online map service, Google also provides APIs (Application Programming Interface) that enables application developers can combine Google maps into developed applications[4]. Google Maps API is a library in the form of JavaScript. Google maps display can be selected by with the wishes of both based on an original photo or an image map of the course[14][4].

\section{Global Positioning System (GPS)}

Global Positioning System (GPS) is a navigation system using satellite technology signals. Satellite sent to earth micro wave then received by a receiver on surface. The receiver will collect information such as time, location in the form of latitude, longitude and the elevation and speed [15].

At the Global Positioning System devices have GPS Tracker also called GPS Tracking. GPS Tracking is a technology AVL (Automated Vehicle Locater) which allows users to track the position of the vehicle, or fleet car in a state of Real-Time[16]. GPS Tracking utilizing a combination of GSM and GPS technology to determine the coordinates of an object, and then translate it in the form of digital maps [17].

\section{RESEARCH METHODS}

\section{A. Location and Place Research}

The research location is housed in the Laboratory of Computer Engineering Academy of Information Management and Computer Mataram for three months, then two months later in the form of test applications from various access points to test application.

\section{B. Data Collection Methods and Data Analysis Methods}

Collecting data in this study used two types of data collection techniques are techniques of collecting primary data and secondary data collection techniques

\section{1) Primary data collection techniques}

Primary data were collected through interviews, questionnaires and observation of direct observation of the object data. Object data in question is data of Global Positioning System (GPS), Google Maps and information about the various tourist attractions in the Province of West Nusa Tenggara.

\section{2) Secondary data collection techniques}

In this study, secondary data obtained by studying, steeped in reference sources or literature relevant to this study are related about Android, Java programming and about the LBS application.

Data analysis method used in this research is descriptive qualitative method.

\section{Research Procedure}

The procedure describes the flow of research studies ranging from the preparation phase, analysis phase, design phase, implementation phase, test phase to the reporting phase. Research procedure can be described as in figure 1:

\section{DESIGN AND IMPLEMENTATION}

\section{A. Design Structure Navigation}

Navigation structure illustrated the flow of display applications that can be comprehended by the users. Navigation structure that used in this application is navigation structure combination that consists of a hierarchical navigation structure, linear and non-linear. Navigation structure can be explained as in figure 2 : 


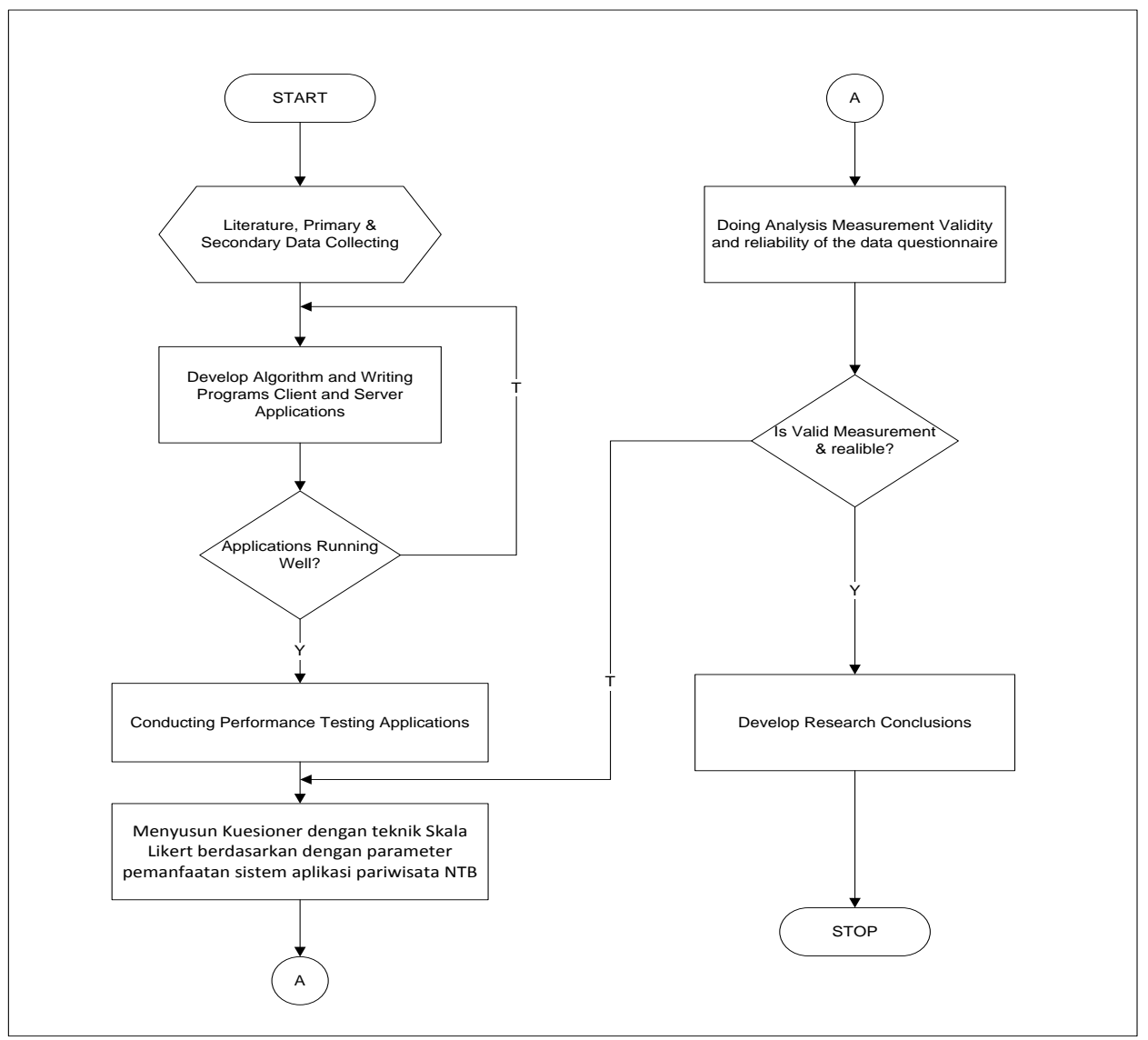

Fig. 1. Research procedure

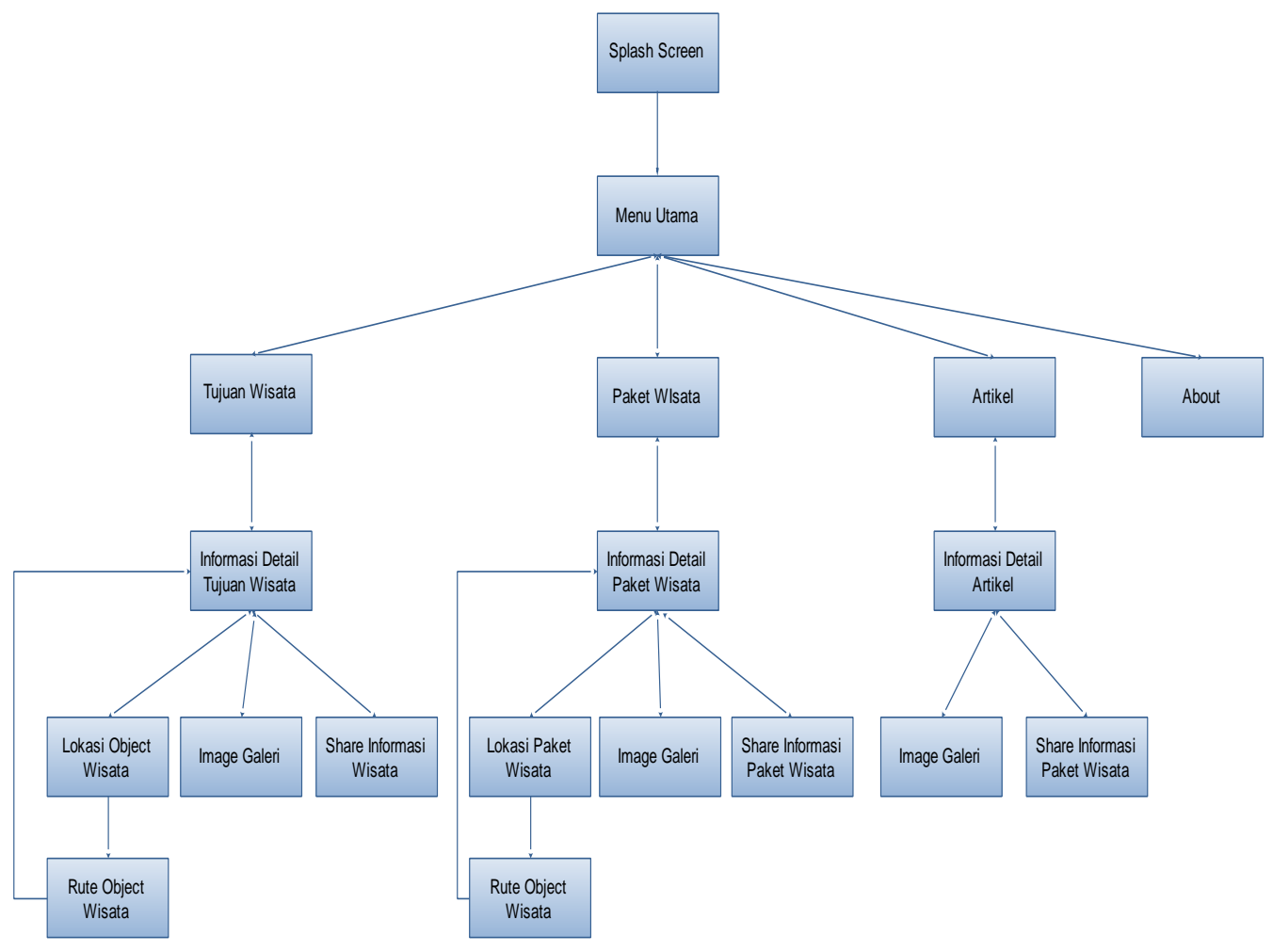

Fig. 2. Structure navigation 
Application starts by displaying a splash screen for 5 seconds to give the application time data collection to the server, after which it will go to the main menu. Further on the main page there are 4 menus that is a tourist destination, travel packages, articles and about. When the user selects the menu of tourist destinations, then the application will display detailed information about tourist destinations in the form of drawings and a detailed explanation of the tourist attractions. On the detail page of the information contained three menus that tourism object location, photo galleries and share travel information. Location object only displays the coordinates tourist attractions on Google Maps, if the coordinates we choose the application will display the path to the navigation or in the form of tourist attractions ranging from the Google Maps to the user's position coordinates tourist attractions.

\section{B. The Need of Hardware and Software}

The application does not require high hardware specs, but the better the hardware specifications used, the better performance of the application will be.

1) Server Specifications

The making of tour android-based application uses the following hardware:

- Processor Intel Core i3-2367M @ $1.40 \mathrm{GHz}$

- Graphics Cards nVidia Geforce GT 620M 1 GB

- RAM 4 GB DDR 3

- Display 14.1" WXGA Acer Crystal Brite LCD

- Hard disk 500GB HDD

2) Android Specifications

To run the travel application android device requires the following specifications:

- Handheld Samsung Galaxy A3

- Operating System Android version 4.4 Kit Kat

- CPU Quad-Core 1.2 GHz Cortex-A53

- Memory RAM 1 GB

- External Memory 16 GB

3) Software Specification

The software used to create applications NTB tour are as follows:

- Java Development Kit (JDK) 8u45-nb-8_0_2 Windows-x64

- Android Software Development Kits (SDK)

- Eclipse Kepler and ADT

- Kies Samsung version 3

C. Design System

The steps of Application System development can be arranged as follows:

1) Literature Study
Literature study conducted to explore the theory and development of existing research and simultaneously understand the problems and solutions.

2) Collecting primary and secondary data

3) Developing algorithms and determine the features provided by the applications that run on both the client side and on the server side as well designing database.

4) Writing program at the Client and Server

5) Performing system testing applications in both the client side and server side.

\section{Design Interface}

\section{1) Main Menu Page}

This page is a page that will appear after the splash screen. This page contains a list of tourist attractions, travel packages, and Tourism news of West Nusa Tenggara. Each item can be selected to display detailed information, photo galleries and tourist sites such as Google maps of the item.

\begin{tabular}{|c|c|c|c|}
\hline $\begin{array}{l}\text { Tempat } \\
\text { Wisata }\end{array}$ & $\begin{array}{l}\text { Paket } \\
\text { Wisata }\end{array}$ & Artikel & About \\
\hline & \multicolumn{2}{|c|}{$\begin{array}{l}\text { Nama Tempat Wisata } \\
\text { Daerah Tempat Wisata } \\
\text { Dipublikasi oleh }\end{array}$} & Tanggal Publikasi \\
\hline & \multicolumn{2}{|c|}{$\begin{array}{l}\text { Nama Tempat Wisata } \\
\text { Daerah Tempat Wisata } \\
\text { Dipublikasi oleh }\end{array}$} & Tanggal Publikasi \\
\hline & \multicolumn{2}{|c|}{$\begin{array}{l}\text { Nama Tempat Wisata } \\
\text { Daerah Tempat Wisata } \\
\text { Dipublikasi oleh }\end{array}$} & Tanggal Publikasi \\
\hline & \multicolumn{2}{|c|}{$\begin{array}{l}\text { Nama Tempat Wisata } \\
\text { Daerah Tempat Wisata } \\
\text { Dipublikasi oleh }\end{array}$} & Tanggal Publikasi \\
\hline & \multicolumn{2}{|c|}{$\begin{array}{l}\text { Nama Tempat Wisata } \\
\text { Daerah Tempat Wisata } \\
\text { Dipublikasi oleh }\end{array}$} & Tanggal Publikasi \\
\hline
\end{tabular}

Fig. 3. Design main menu page

2) Detail Information Page

This page displays detailed information about tourist attractions. On this page, there is a menu photo gallery, tourist sites and share information through social media.

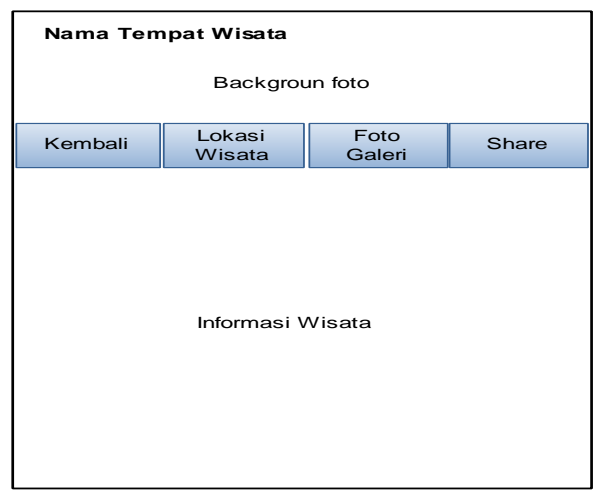

Fig. 4. Design detail information page 


\section{3) Tourism Route Page}

Tourism route page showed travel route or track route to the destination from tourists' location to the place where the position is.

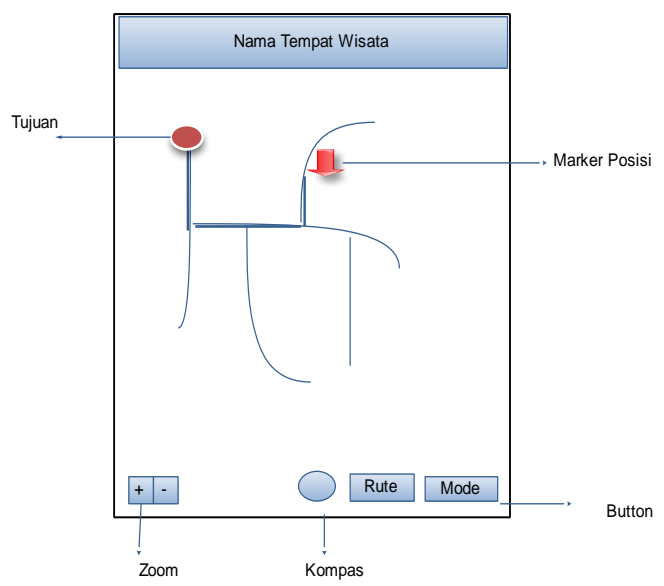

Fig. 5. Page tourism route design

\section{RESULTS AND DISCUSSION}

\section{A. Test Result}

The results from testing of each component will be showed in the following table:

TABLE I. RESUlTS FROM THE TESTING

\begin{tabular}{|l|l|l|l|}
\hline No & Testing & Information & Result \\
\hline 1 & $\begin{array}{l}\text { Splash screen } \\
\text { display }\end{array}$ & $\begin{array}{l}\text { Splash screen displays for 5 } \\
\text { seconds }\end{array}$ & Valid \\
\hline $\begin{array}{l}\text { Dotification if } \\
\text { there is no } \\
\text { internet } \\
\text { connection }\end{array}$ & $\begin{array}{l}\text { This page appears when there is no } \\
\text { internet connection on the } \\
\text { Smartphone }\end{array}$ & Valid \\
\hline 3 & $\begin{array}{l}\text { Main menu } \\
\text { display }\end{array}$ & $\begin{array}{l}\text { The main menu displays a list of } \\
\text { tourist attractions in a full page. If } \\
\text { the page scrolls down next tourist } \\
\text { spot, the data will be displayed. }\end{array}$ & Valid \\
\hline 5 & $\begin{array}{l}\text { Tetail } \\
\text { information } \\
\text { display }\end{array}$ & $\begin{array}{l}\text { This page showed detailed } \\
\text { information about tourist } \\
\text { attractions, including pictures and } \\
\text { detailed description. }\end{array}$ & Valid \\
\hline 6 & $\begin{array}{l}\text { Google maps } \\
\text { display }\end{array}$ & $\begin{array}{l}\text { This page shows Google maps to } \\
\text { show the location of the selected } \\
\text { tourist spots and marked with a } \\
\text { marker Google maps. }\end{array}$ & Valid \\
\hline 7 & $\begin{array}{l}\text { Toogle maps } \\
\text { display }\end{array}$ & $\begin{array}{l}\text { This page appears when selecting } \\
\text { marker on the page Google maps } \\
\text { tourist sites. This page displays the } \\
\text { route to the tourist attractions } \\
\text { along the travel time. }\end{array}$ & Valid \\
\hline display & $\begin{array}{l}\text { This page displays photos of the } \\
\text { beauty of the tourist sites are } \\
\text { selected. The photos displayed in } \\
\text { the form of a slide show that slides } \\
\text { left to the right. }\end{array}$ & Valid \\
\hline
\end{tabular}

From the table above, it can be concluded that the application is running by the good design without any error when run on the emulator on a Smartphone device. This application has also been tested by 50 different users on different Smartphone as well as on different screen sizes.
From the results of these experiments, there were no problems or errors on run time.

\section{B. Display Results}

The result of the design that has been gained found that the application has been implemented in the form of Android applications. This application will run if the device is connected to the internet and GPS to determine the tourist position or user applications. The application will display a page splash screen for 5 seconds to allow time for data collection on the server and then it will display the main menu page as shown below:

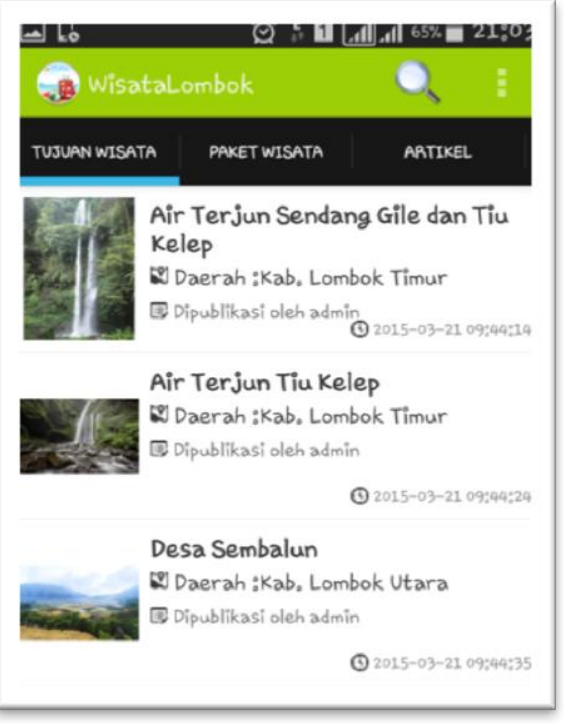

Fig. 6. Main menu page

To view detailed information, select the type of Tourism information that will be displayed. On this page simply displays a list of tourist attractions, tour packages offered by the agent as well as news about Tourism activities. To view detailed information about each of the attractions, tour packages and select the articles or news items you want to display detail information pages that appear attractions such as the following picture:

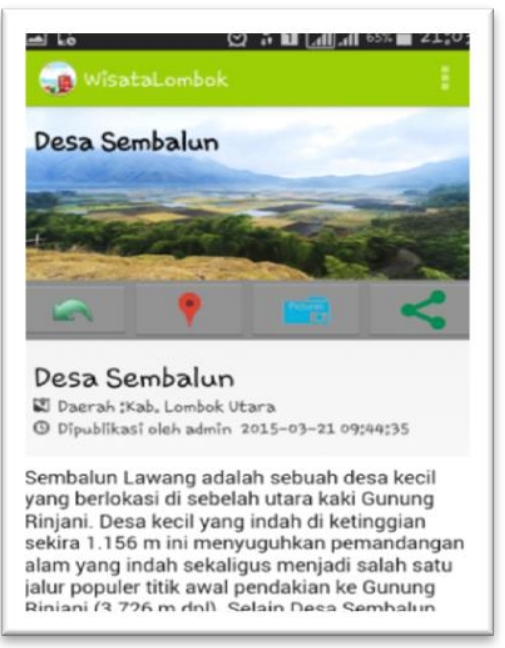

Fig. 7. Detail information Tourism page 
This page displays detailed information about tourist attractions. To view the position or the select key tourist sites Google marker so that it will display the form Google Maps travel position such as the picture below:

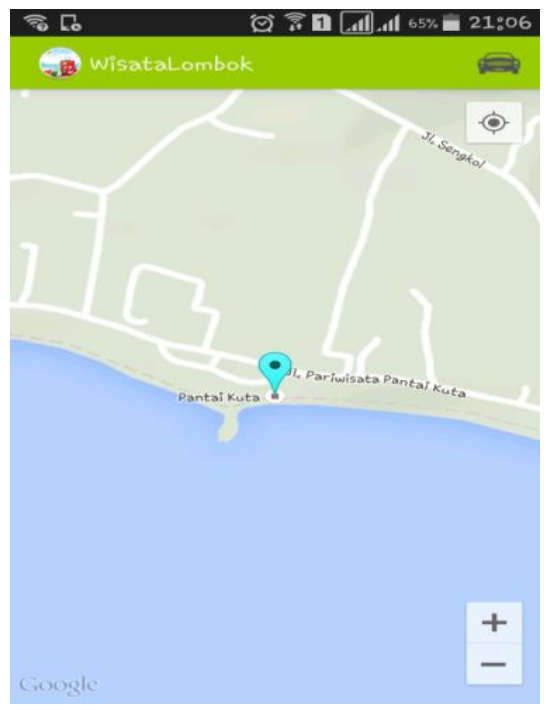

Fig. 8. Google maps page

This page simply displays the marker Google maps of the location of the tourist attractions. To view the route of the location, click the marker that appears. There will be a deal, if she or he wants to use Google maps or not and the choice of using the route or pathway that will be used. Choose the shortest path or paths with the shortest travel time on Google maps so it will display the route as shown below:

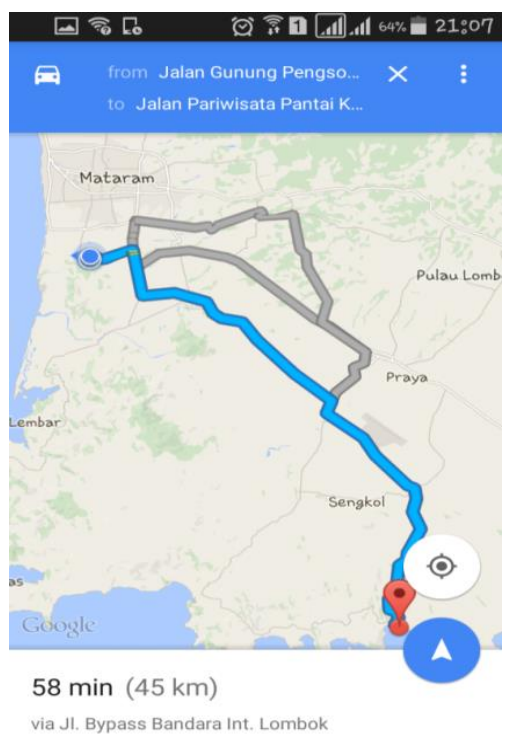

Fig. 9. Google maps route tourism page

Also there is a button to display the position as well as the tourist attractions, there is also a menu to display the photo gallery that displayed the location of the tourist attractions in the form of a grid. The displayed image can be displayed in full-screen size by scrolling left or to right to display the next image.

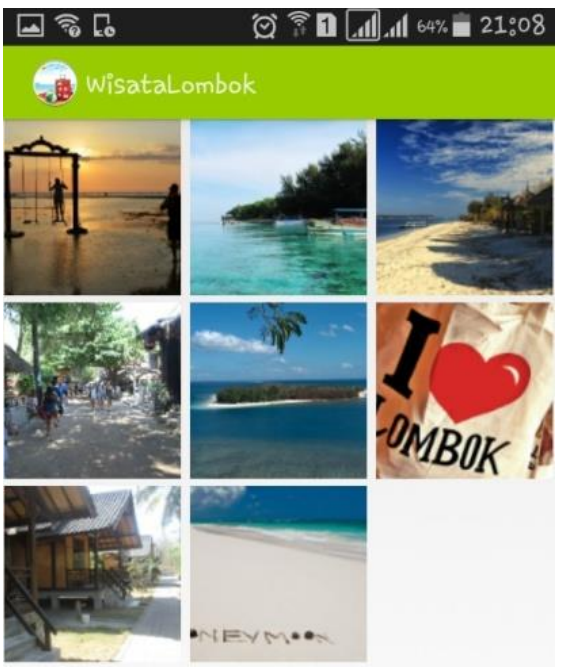

Fig. 10. Image gallery page

\section{CONCLUSION}

From the results of the study, based on the correspondence amongst the input, process, and output, it can be concluded that the Tourism applications can run well on android or Smartphone. The application can be run if the Smartphone has a good access to the Internet and have an active GPS. The travel application provides convenience for the tourists when visiting West Nusa Tenggara in finding the Tourism sites.

\section{BIBLIOGRAPHY}

[1] A. Subhani, "Potensi obyek wisata pantai di kabupaten lombok timur," 2010 .

[2] Z. Amrulloh, "Pemberdataan Masyarakat Berbasis Pariwisata pada Dusun Tradisional Sasak Sade Lombok NTB,” 2014.

[3] A. Sasongko, J. S. Informasi, F. Ilmu, and T. Informasi, "Aplikasi pemesanan makanan dan minuman pada rumah makan."

[4] D. G. Parrangan, "Pengembangan Indoor Location Based Service Menggunakan Wireless Positioning Pada Android," 2013.

[5] B. Anwar, H. Jaya, P. I. Kusuma, P. Studi, and S. Komputer, "Implementasi Location Based Service Berbasis Android untuk Mengetahui Posisi User," pp. 121-133, 2013.

[6] B. R. Rompas, a a E. Sinsuw, S. R. U. a Sompie, and a S. M. Lumenta, "Aplikasi Location-Based Service Pencarian Tempat Di Kota Manado Berbasis Android," no. 1, pp. 1-11, 2009.

[7] M. G. Aribowo, "Perancangan Aplikasi Pencarian Lokasi Bank Di Yogyakarta Dengan Location Base Service Untuk Android,” 2013.

[8] N. T. Z. A, "Membangun Aplikasi Layanan Pencarian Lokasi Kuliner Terdekat Di yogyakarta Berbasis Android," 2012.

[9] B. D. Sarode and P. P. P. Karde, "Personal Service Areas for LocationBased Wireless Web Applications on Android Platform," vol. 4, no. 1, pp. 205-210, 2015.

[10] A. Sinsuw and X. Najoan, "Prototipe Aplikasi Sistem Informasi Akademik Pada Perangkat Android," pp. 1-10, 2013.

[11] W. Kusuma, A. K. Yapie, and E. S. Mulyani, "Aplikasi Location Based Service (LBS) Taman Mini Indonesia Indah (TMII) Berbasis Android," Semin. Nas. Apl. Teknol. Inf. 2013, pp. 13-18, 2013.

[12] A. Kushwaha and V. Kushwaha, "Location Based Services using Android mobile Operating System.pdf," Int. J. Adv. Eng. Technol., vol. 1, no. 1, pp. 14-20, 2011.

[13] L. Calderoni, D. Maio, and P. Palmieri, "Location-aware mobile services for a smart city: Design, implementation and deployment," J. Theor. Appl. Electron. Commer. Res., vol. 7, no. 3, pp. 74-87, 2012. 
[14] A. D. Laksito, "Analisis Model Kematangan Tata Kelola teknologi Informasi di STMIK AMIKOM Yogyakarta menggunakan Framework COBIT," 2012.

[15] M. Singhal and A. Shukla, "Implementation of Location based Services in Android using GPS and Web Services," Int. J. Comput. Sci. Issues, vol. 9, no. 1, pp. 237-242, 2012.
[16] Wahyu Widayanto, "Perancangan Aplikasi Pengingat berdasarkan Location Base Service Berbasis Android," 2013.

[17] S. Kumar, M. Qadeer, and a Gupta, "Location based services using android (LBSOID),” Internet Multimed. Serv. ..., pp. 1-5, 2009. 